\title{
The emulsifying effect of biosurfactants produced by food spoilage organisms in Nigeria
}

\author{
Christianah O. Ogunmola ${ }^{a^{*}}$ and Olusimbo O. Aboaba ${ }^{\mathrm{a}}$ \\ a Department of Microbiology, University of Lagos Akoka, Lagos State, Nigeria \\ ${ }^{*}$ Corresponding author \\ wumae2009@yahoo.com \\ TEL: $+234(0) 8038546954$
}

Received: 15 July 2014; Published online: 18 April 2016

Invited paper from the $3^{\text {rd }}$ International ISEKI_Food Conference - ISEKI_Food 2014 - Bridging Training and Research for Industry and the Wider Community - Food Science and Technology Excellence for a Sustainable Bioeconomy

\begin{abstract}
Food spoilage organisms were isolated using standard procedures on Nutrient Agar, Cetrimide Agar and Pseudomonas Agar Base (supplemented with CFC). The samples were categorized as animal products (raw fish, egg, raw chicken, corned beef, pasteurized milk) and plant products (vegetable salad, water leaf (Talinium triangulare), boiled rice, tomatoes and pumpkin leaf (Teifairia occidentalis).They were characterised as Pseudomonas putida, Pseudomonas aeruginosa, Pseudomonas stutzeri, Burkholderia pseudomallei, Serratia rubidaea, Corynebacterium pilosum, Bacillus subtilis, Bacillus mycoides, Bacillus laterosporus, Bacillus laterosporus, Serratia marcescens, Bacillus cereus, Bacillus macerans, Alcaligenes faecalis and Alcaligenes eutrophus. Preliminary screening for biosurfactant production was done using red blood haemolysis test and confirmed by slide test, drop collapse and oil spreading assay. The biosurfactant produced was purified using acetone and the composition determined initially using Molisch's test, thin layer chromatography and gas chromatography mass spectrometry. The components were found to be ethanol, amino acids, butoxyacetic acid, hexadecanoic acid, oleic acid, lauryl peroxide, octadecanoic acid and phthalic acid. The producing organisms grew readily on several hydrocarbons such as crude oil, diesel oil and aviation fuel when used as sole carbon sources. The purified biosurfactants produced were able to cause emulsification of kerosene (19.71-27.14\%) as well as vegetable oil (16.91-28.12\%) based on the emulsification index. This result suggests that the isolates can be an asset and further work can exploit their optimal potential in industries.
\end{abstract}

Keywords: Biosurfactants; Hydrocarbon; Emulsification; Heteropolymers

\section{Introduction}

Biosurfactants or microbial surfactants are surface metabolites produced by bacteria, yeast and fungi having very different chemical structures and properties (Ron \& Rosenberg, 2001). These biosurfactants are amphiphilic molecules of microbial origin whose hydrophobic and hydrophilic domains depend on the carbon sub- strate and the organism strain. These hydrophobic and hydrophilic properties have found application in an extremely wide variety of industrial processes involving emulsification, foaming, detergency, wetting, dispersing or solubilization (Gautam \& Tyagi, 2006). Nowadays, biosurfactants are used in industries as a cosmetic and special chemical substances, food, pharmaceutics, agriculture, cleansers, enhanced oil recov- 
ery and bioremediation of oil-contaminated sites (Kitamoto, Isoda, \& Nakahara, 2002). They are potential alternatives of chemically synthesized surfactant in a variety of applications because of their advantages such as lower toxicity, higher biodegradability, better environmental compatibility, lower critical micelle concentration, ease of production, ability to be synthesized from renewable resources, higher foaming, higher selectivity, specific activity at extreme temperature, $\mathrm{pH}$ and salinity (Ilori, Amobi, \& Odocha, 2005). Many microorganisms have the ability to produce a wide range of biosurfactants, as such initial classification was made into two; based on molecular weights, properties and cellular localizations. The low molecular weight biosurfactants e.g. glycolipids, lipopeptides, flavolipids, corynomycolic acids and phospholipids, lower the surface and interfacial tensions at the air/water interfaces while the high molecular weights are called bioemulsans (such as emulsan, alasan, liposan, polysaccharides and protein complexes) and are more effective in stabilizing oil-in-water emulsions (Franzetti et al., 2009). Scientists have commonly turned to contaminated sites as sources for the isolation of biosurfactant-producing and hydrocarbondegrading microorganisms which have produced varied results such as Peudomonas fluorescens from petroleum-contaminated soil (Barathi \& Vasudevan, 2001), naphthalene degrading Bacillus pumilis strain isolated from oil sludge (Calvo, Toledo, \& Gonzalez-Lopez, 2004), and Candida glabrata UCP 1002 obtained from petroleum hydrocarbons contaminated soil samples (Sarubbo, de Luna, \& de Campos-Takaki, 2006). An alternative and largely untapped source of biosurfactant-producing bacteria is food. The objective of this work is to isolate biosurfactantproducing bacteria from food waste as an alternative to environmental samples (water and soil) and to also screen for emulsification ability.

\section{Materials and Methods}

\subsection{Sample collection}

Food samples were obtained from kitchen wastes and transported to the laboratory in sterile plas- tic containers. The crude oil, aviation fuel, diesel oil, kerosene and cooking oil (Gino vegetable oil) were obtained from local sources.

\subsection{Isolation of organisms}

The microbial population in the food samples was assayed by standard plate count method using the spread plate technique. For each sample, $20 \mathrm{~g}$ was aseptically removed and homogenised for $2 \mathrm{~min}$ in $180 \mathrm{ml}$ Peptone water (Lab m laboratories, UK). A tenfold serial dilution $\left(10^{-1}\right.$ to $10^{-8}$ ) was prepared and an aliquot of $0.1 \mathrm{ml}$ plated in triplicate on Nutrient Agar (Biotec laboratories, UK), Pseudomonas Agar base (supplemented with CFC) (Biomark laboratories, India) and Cetrimide Agar (Lab m laboratories, UK).

\subsection{Preliminary test for biosurfactant production}

\section{Haemolysis}

This was done using the method developed by Mulligan, Cooper, and Neufeld (1984). Colonies from $18 \mathrm{~h}$ old cultures of the isolates were inoculated on Sheep Blood Agar plates and incubated for $48-72 \mathrm{~h}$ at $37^{\circ} \mathrm{C}$. Positive strains cause lysis of the blood cells and exhibit a colourless, transparent ring around the colonies.

\section{Oil spreading assay}

The oil spreading assay was developed by Morikawa, Hirata, and Imanaka (2000). This was done by placing $10 \mu \mathrm{l}$ of crude oil on the surface of $40 \mathrm{ml}$ of distilled water in a Petri dish to form a thin oil layer. Culture supernatant (10 $\mu \mathrm{l}$ of $10^{-6} \mathrm{cfu} / \mathrm{ml}$ ) was gently placed on the centre of the oil layer. If biosurfactant is present in the supernatant, the oil is displaced and a clearing zone is formed. The diameter of this clearing zone on the oil surface is the surfactant activity which is the oil displacement activity.

\section{Drop collapse assay}

Cell free supernatants obtained from the isolates when grown in Nutrient Broth (Lab m laboratories, UK) for $24 \mathrm{~h}$ were tested for their ability to 
collapse on the surface of an oil drop, as described by Jain, Lee, and Trevors (1992). This was done by adding $40 \mu \mathrm{l}$ of cooking oil (vegetable oil) to the surface of a clean glass slide and allowing to equilibrate to room temperature $\left(25^{\circ} \mathrm{C}\right)$ for $1 \mathrm{~h}$. A loopful of an overnight culture of each isolate was suspended in $150 \mu \mathrm{l}$ sterile distilled water and $50 \mu \mathrm{l}$ of the cell suspension was then added to the surface of an oil drop. The shape of the drop on the surface of oil was inspected visually after $1-2$ min. Biosurfactant-producing isolates produced collapsed drops while those that did not remained stable. Sterile distilled water was used as the control.

\section{Slide test}

A wire loop was aseptically used to pick an inoculum from a $24 \mathrm{~h}$ old culture on Nutrient Agar (Lab m laboratories, UK). A droplet of Normal Saline (0.85\% Sodium Chloride) was placed on it to make a wet preparation of the bacterial isolate on a grease free slide. The slide was slanted at $45^{\circ} \mathrm{C}$ and then observed visually for the flow of the wet preparation over the surface of the glass slide. Flow of the wet preparation of bacteria over the glass slide was recorded as a positive result (Olutola, Famurewa, \& Sonntag, 2000)

\subsection{Data Analysis}

The biosurfactant-producing isolates were characterized and identified on the basis of their cultural and cellular morphologies, Gram reactions and several biochemical reactions using the taxonomic Schemes of Bergey's Manual of Determinative Bacteriology (Holt, Krieg, Sneath, Stalely, \& Williams, 1994) and API 20 NE (Analytical Profile Index) kit (BioMérieux, USA).

\subsection{Biosurfactant production and hydrocarbon utilization assay}

The isolates were cultured on Nutrient Agar, incubated at $37^{\circ} \mathrm{C}$ for $24 \mathrm{~h}$. After $24 \mathrm{~h}$, a loopful of each isolate was inoculated into $9 \mathrm{ml}$ of sterile distilled water, shaken thoroughly for even distribution and $1 \mathrm{ml}$ aliquot transferred into separate $100 \mathrm{ml}$ minimal salt media, supplemented with $1 \%$ hydrocarbon as carbon source (Barathi \& Vasudevan, 2001). Crude oil, diesel oil and aviation fuel were used. It was incubated at $30^{\circ} \mathrm{C}$ on a shaker incubator (Sheldon Manufacturing, Inc., USA) at $120 \mathrm{rpm}$ for 21 days. Hydrocarbon utilization assay was carried out by monitoring the growth pattern of isolates every $72 \mathrm{~h}$ by cell count and visual observation. To obtain a viable cell count, a tenfold serial dilution $\left(10^{-1}\right.$ to $\left.10^{-8}\right)$ was plated in duplicate using the pour-plate technique on Nutrient Agar and incubated aerobically at $37^{\circ} \mathrm{C}$ for $24 \mathrm{~h}$ with an un-inoculated flask as control. Increase in cell number and physical disappearance of the hydrocarbon indicates utilization (Adebusoye, Amund, Ilori, Domeih, \& Okpuzor, 2008).

\subsection{Biosurfactant extraction and purification}

Pure culture of each of the biosurfactantproducing isolates was inoculated into $100 \mathrm{ml}$ minimal salt media, supplemented with hydrocarbon as carbon source and incubated for 21 days. Culture broth was centrifuged at 5,000 rpm for $20 \mathrm{~min}$ at $4^{\circ} \mathrm{C}$ to obtain cell free supernatant. The biosurfactant was extracted by adding equal volume of acetone to the supernatant and incubated at $4^{\circ} \mathrm{C}$ for $24 \mathrm{~h}$. The mixture was centrifuged at 5,000 rpm for $20 \mathrm{~min}$ at $4^{\circ} \mathrm{C}$ and the pooled extracts evaporated to dryness over a water bath at $45-50^{\circ} \mathrm{C}$ (Patil \& Chopade, 2001).

\subsection{Biochemical characterization of biosurfactants}

\section{Test for carbohydrate}

This test was carried out using Molisch's test (Pinzon \& Ju, 2009). Two drops of Molisch's reagent ( $\alpha$-naphtol dissolved in ethanol (SigmaAldrich, Dorset, UK)) was added to $2 \mathrm{ml}$ of the cell free supernatant obtained by centrifugation and then mixed together. After mixing, $2 \mathrm{ml}$ of concentrated sulphuric acid was added slowly down the side of the test tube placed in a sloppy condition without mixing to form a bottom layer. The positive reaction was indicated by the ap- 
pearance of a purple ring at the interface between the acid and the test layers.

\section{Test for peptides and lipids}

Thin layer chromatography (TLC) of the extracted biosurfactants from the I8 isolates was carried out by spotting $10 \mu \mathrm{l}$ volume of extracted biosurfactant dissolved in methanol (Sigma-Aldrich, Dorset, UK) onto silica gel aluminium TLC plates (FMC Biopolymer, Philadelphia, PA, USA)and developed in chloroform:methanol:water (65:15:2, vol/vol/vol) (Sim, Ward, \& Li, 1997). For detection of peptides the plates were air dried, sprayed with ninhydrin $(0.2 \%$ in $95 \%$ ethanol), air dried once more and heated at $110^{\circ} \mathrm{C}$ for $10 \mathrm{~min}$. Plates were also viewed under UV light before staining with ninhydrin while for detection of lipids, the plates were stained with iodine. Migration distances of sample spots, before and after staining, relative to the mobile phase ( $\mathrm{R} f$ values) were calculated.

\subsection{Component identification of biosurfactants}

The biosurfactants were analyzed by gas chromatography mass spectrometry (GC-MS) for components identification (Yakimov, Timmis, Wray, \& Fredrickson, 1995). The partially purified biosurfactant was converted into a volatile compound using exane (Sigma-Aldrich, Dorset, UK).The exane was removed from the sample by decanting it into a beaker using a separating funnel, cotton wool was put in a Pasteur pipette then anhydrous sodium sulphate (Sigma-Aldrich, Dorset, UK) was poured into it before pouring the sample to remove the remaining moisture from the sample. The filtered sample was then allowed to stand for 2 min to dry before pouring into a $\mathrm{GC}$ vial. GC-MS analysis was performed using Agilent 6890N with Agilent Technologies (United States) 123-5032 DB-5 (30 m × $0.25 \mathrm{~mm} \times 0.25 \mu \mathrm{m})$ capillary column and SGE $10 \mu \mathrm{L}$ syringe. Distillate samples $(1 \mu \mathrm{L})$ were injected and oven temperatures was programmed from $60^{\circ} \mathrm{C}$ to $200^{\circ} \mathrm{C}$ at the rate of $6^{\circ} \mathrm{C} / \mathrm{min}$ and then isothermally held for $11 \mathrm{~min}$ until the analy- sis was completed then the peaks were compared with standards.

\subsection{Emulsification capacity assay}

The assay for emulsification capacity of biosurfactants was developed by Cooper and Goldenberg (1987). Kerosene and cooking oil (vegetable oil) were used. The isolates were grown in Nutrient Broth at $37^{\circ} \mathrm{C}$ for $24 \mathrm{~h}$; the supernatant of the biosurfactant-producing isolates was obtained by subjecting each isolate contained in the Nutrient Broth to centrifugation ( $5 \mathrm{~min}, 5000 \mathrm{rpm}$ ). Three $\mathrm{ml}$ of kerosene and cooking oil was added to 2 $\mathrm{ml}$ of cell free supernatant for each isolate differently and then vortexed for 2 min using a vortex mixer (Eppendorf, North America). It was then allowed to stand for $24 \mathrm{~h}$ and the emulsification index was measured and recorded using the formula below. Sterile Nutrient Broth served as a control. The emulsion index $E_{24}$ is calculated as the ratio of the height of the emulsion layer and the total height of liquid:

$$
E_{24}=\frac{\text { Height of emulsion formed }}{\text { Total height of solution }} \times 100
$$

\section{Results and Discussion}

\subsection{Results}

\section{Isolation}

A total of 54 bacterial isolates were isolated from the food wastes. Twenty organisms were isolated from Nutrient Agar (NA), 23 from Pseudomonas Agar Base (PAB) and 11 from Cetrimide Agar (CE). The isolates were designated $R_{1}$, Fish PAB, $\mathrm{TO}_{2} \mathrm{CE}, \mathrm{TO}_{1} \ldots \ldots . . \mathrm{EPAB}_{2} 1$.

\section{Biosurfactant producing isolates}

Eighteen isolates out of the 54 isolates obtained were found to produce biosurfactants (Table 1).

\section{Identification of isolates}

The phenotypic characterization of the isolates revealed the presence of Pseudomonas 
Table 1: Biosurfactant producing ability of isolates

\begin{tabular}{|c|c|c|c|c|c|c|c|}
\hline $\mathrm{S} / \mathrm{NO}$ & $\begin{array}{l}\text { Isolate } \\
\text { code }\end{array}$ & Organisms & Origin & Hemolysis & $\begin{array}{l}\text { Slide } \\
\text { test }\end{array}$ & $\begin{array}{c}\text { Drop } \\
\text { Collapse }\end{array}$ & $\begin{array}{c}\text { Oil } \\
\text { Spreading } \\
\text { Assay }\end{array}$ \\
\hline 2 & Fish PAB & $\begin{array}{l}\text { Burkholderia } \\
\text { pseudomallei }\end{array}$ & fish & + & + & + & + \\
\hline 3 & $\mathrm{EPAB}_{2}^{2}$ & Serratia rubidaea & egg & + & + & - & + \\
\hline 5 & $\mathrm{EPAB}_{2} 1$ & Burkholderia pseudomallei & egg & + & + & + & + \\
\hline 6 & $\mathrm{~W}_{1} \mathrm{CE}$ & Pseudomonas putida & water leaf & + & - & + & + \\
\hline 7 & $\mathrm{~W}_{2} \mathrm{CE}$ & Pseudomonas aeruginosa & water leaf & + & - & + & + \\
\hline 8 & $\mathrm{~W}_{3} \mathrm{CE}$ & Bacillus mycoides & water leaf & + & + & + & + \\
\hline 9 & $\mathrm{~W}_{4} \mathrm{PAB}$ & Pseudomonas stutzeri & water leaf & + & + & + & + \\
\hline 14 & $\mathrm{SPAB}_{2}$ & Corynebacterium pilosum & salad & + & + & + & + \\
\hline 15 & $\mathrm{MNA}_{1}$ & Serratia marcescens & milk & + & - & + & + \\
\hline 16 & $\mathrm{MNA}_{3}$ & Bacillus circulans & milk & + & + & + & + \\
\hline 17 & $\mathrm{M}_{3} \mathrm{PAB}$ & Bacillus subtilis & milk & + & + & + & + \\
\hline 18 & CHPAB & Pseudomonas stutzeri & chicken & + & + & + & + \\
\hline
\end{tabular}

putida, Pseudomonas aeruginosa, Pseudomonas stutzeri, Burkholderia pseudomallei, Serratia rubidaea, Corynebacterium pilosum, Bacillus subtilis, Bacillus mycoides, Bacillus laterosporus, Serratia marcescens, Bacillus cereus, Bacillus macerans, Alcaligenes faecalis and Alcaligenes eutrophus. This indicates that these spoilt food samples contained $33.3 \%$ of Bacillus spp., $27.8 \%$ of Pseudomonas spp., $11.1 \%$ of Alcaligenes spp., $11.1 \%$ of Burkholderia spp., $11.1 \%$ of Serratia spp. and $5.6 \%$ of Corynebacterium spp.

\section{Hydrocarbon utilization}

Isolates identified as Pseudomonas putida, Pseudomonas aeruginosa, Pseudomonas stutzeri, Burkholderia pseudomallei and Alcaligenes faecalis were able to utilize the three hydrocarbons (crude oil, diesel oil and aviation fuel) for growth while Bacillus cereus and Bacillus subtilis were able to utilize crude oil and diesel oil (Table 2). The growth pattern of the organisms that were able to utilize crude oil was determined by plating out an aliquot every $72 \mathrm{~h}$ (Figure 1).

\section{Biochemical characterization of biosurfactants}

Preliminary biochemical characterization of the purified biosurfactants confirmed the presence of carbohydrate while TLC analysis confirmed the presence of lipid and protein moieties with $\mathrm{R} f$ values ranging from 0.79-1.00 (Table 3).

\section{Component identification of biosurfactants}

GC-MS detected the presence of ethanol, amino acids, butoxyacetic acid, hexadecanoic acid, oleic acid, lauryl peroxide, octadecanoic acid and phthalic acid (Figure 2).

\section{Emulsification assay}

The highest emulsification index for kerosene was $27.14 \%$ while the lowest was $19.71 \%$ and that of vegetable oil was $28.12 \%$ while the lowest was $16.91 \%$ (Table 4). 
Emulsifying effect of biosurfactants produced by food spoilage organisms $\mid 1$

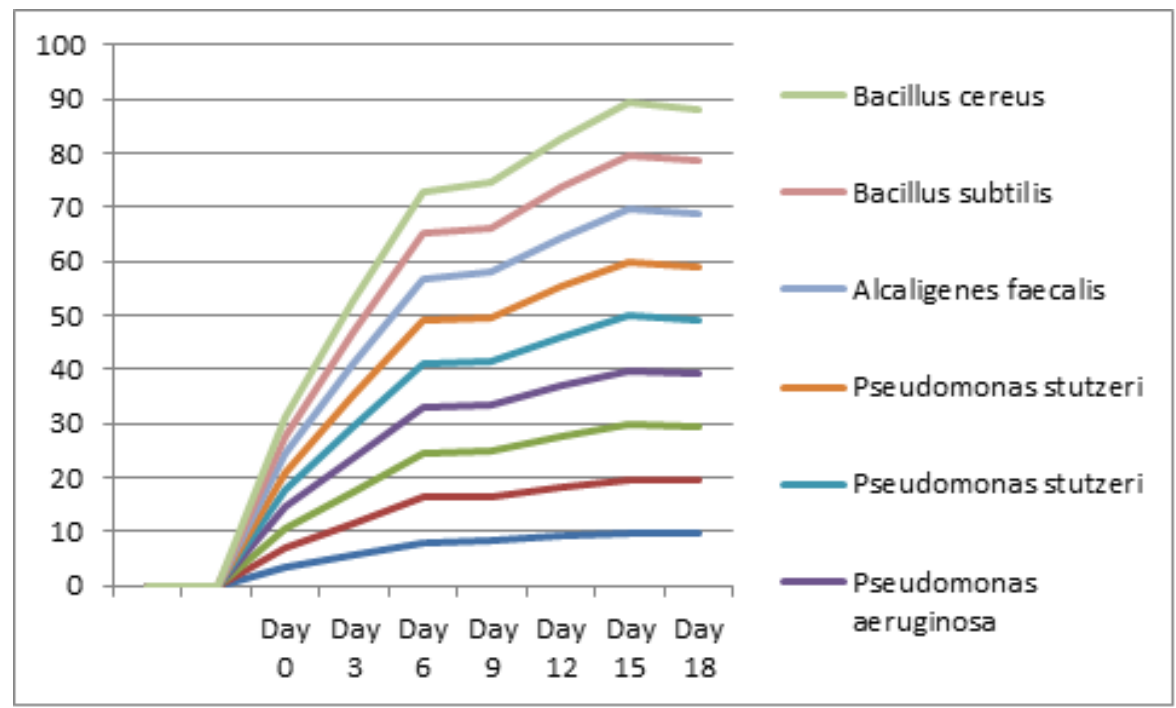

Figure 1: Growth pattern of biosurfactanct producing organisms on crude oil within 21 day incubation period

Table 2: Rate of hydrocarbon utilization

\begin{tabular}{llll}
\hline Organisms identified & Crude oil & Diesel oil & Aviation fuel \\
\hline Pseudomonas putida & $+++^{a}$ & +++ & +++ \\
Pseudomonas aeruginosa & +++ & +++ & +++ \\
Pseudomonas stutzeri & +++ & +++ & +++ \\
Pseudomonas stutzeri & +++ & +++ & + \\
Burkholderiapseudomallei & +++ & $+{ }^{c}$ & + \\
Burkholderiapseudomallei & +++ & +++ & +++ \\
Bacillus subtilis & +++ & +++ & $-{ }^{d}$ \\
Alcaligenesfaecalis & +++ & ++ & $++{ }^{b}$ \\
Bacillus cereus & +++ & +++ & - \\
Control & - & - & - \\
\hline Key: ${ }^{a}$ 100\% utilization of hydrocarbon; ${ }^{b} 80 \%$ utilization of hydrocarbon; \\
${ }^{c} 40 \%$ utilization of hydrocarbon; ${ }^{d} 0 \%$ utilization of hydrocarbon
\end{tabular}

Table 3: Thin layer chromatography biosurfactants

\begin{tabular}{llll}
\hline S/NO & Organisms isolated & Origin & Rf Values \\
\hline 1 & Pseudomonas putida $\left(\mathrm{W}_{1} \mathrm{CE}\right)$ & water leaf & $0.85,0.98$ \\
2 & Pseudomonas aeruginosa $\left(\mathrm{W}_{2} \mathrm{CE}\right)$ & water leaf & $0.88,0.98$ \\
3 & Pseudomonas stutzeri $\left(\mathrm{R}_{1}\right)$ & rice & $0.79,0.96$ \\
4 & Pseudomonas stutzeri $\left(\mathrm{W}_{4} \mathrm{PAB}\right)$ & water leaf & $0.86,0.98$ \\
5 & Burkholderia pseudomallei $\left.(\mathrm{EPAB})_{1}^{2}\right)$ & egg & $0.87,0.98$ \\
6 & Burkholderia pseudomallei $(\mathrm{FISH} \mathrm{PAB})$ & fish & 1.00 \\
7 & Bacillus subtilis $\left(\mathrm{M}_{3} \mathrm{PAB}\right)$ & milk & $0.86,0.98$ \\
8 & Alcaligenes faecalis $\left(\mathrm{TO}^{1}\right)$ & tomatoes & $0.82,0.96$ \\
9 & Bacillus cereus $(\mathrm{PL})$ & pumpkin leaf & $0.86,0.98$ \\
\hline
\end{tabular}

IJFS | April 2016 | Volume $5 \mid$ pages 12-21 


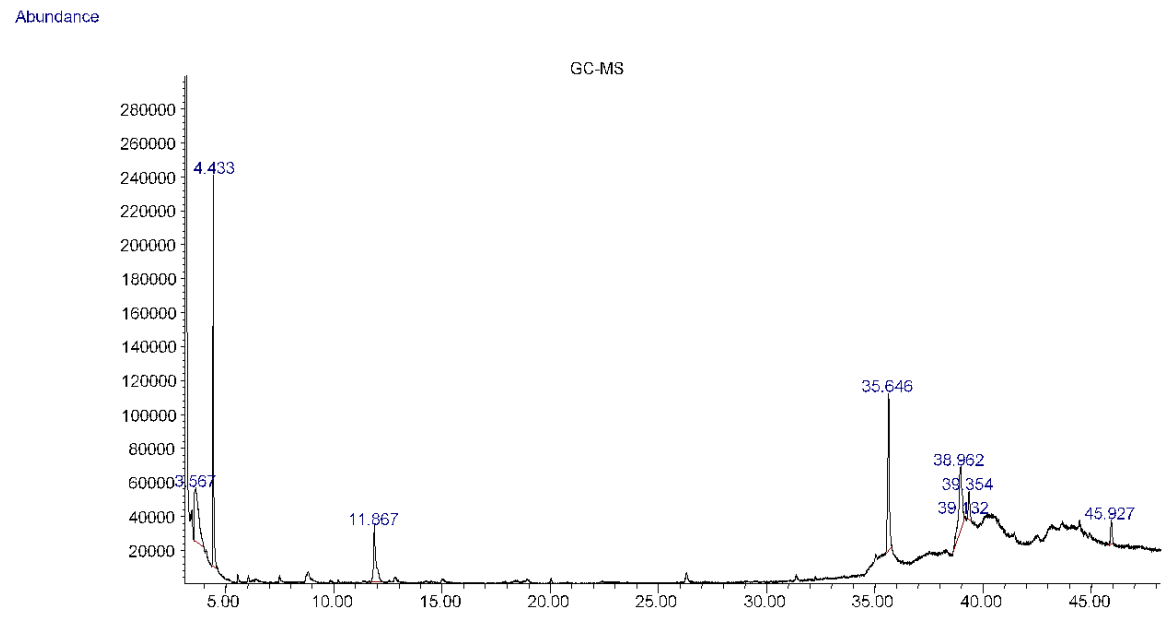

Figure 2: GC-MS of biosurfactant

Table 4: Thin layer chromatography biosurfactants

\begin{tabular}{lll}
\hline Organisms identified & $\begin{array}{l}\text { Emulsification index (\%) } \\
\text { on kerosene }\end{array}$ & $\begin{array}{l}\text { Emulsification index (\%) } \\
\text { on vegetable oil }\end{array}$ \\
\hline Pseudomonas putida & 24.41 & 28.12 \\
Pseudomonas aeruginosa & 25.37 & 26.41 \\
Pseudomonas stutzeri & 23.53 & 23.28 \\
Pseudomonas stutzeri & 22.79 & 25.76 \\
Burkholderia pseudomallei & 27.14 & 26.96 \\
Alcaligenes faecalis & 21.43 & 17.91 \\
Burkholderia pseudomallei & 24.31 & 26.36 \\
Bacillus cereus & 19.71 & 16.91 \\
Bacillus subtilis & 26.38 & 27.94 \\
\hline
\end{tabular}

\subsection{Discussion}

Eighteen isolates belonging to six genera were found to be biosurfactant producers. All 18 bacterial isolates tested positive for biosurfactant producing ability as shown by haemolysis, slide test, drop collapse test and oil spreading assay. Mulligan (2005) recommended blood agar lysis as a preliminary screening method for biosurfactant production. However, in some cases haemolytic assay excluded many good biosurfactant producers; hence in this present study, the presence was confirmed as positive results using slide test, drop collapse test and oil spreading assay. It has been reported by Nitschke and Pastore (2006) that microbes produce biosurfactants, especially during growth on waterimmiscible substrates. Crude oil, diesel oil and aviation fuel were used as sole carbon and energy sources in this study to assess the emulsification ability of these organisms and concomitant biosurfactant production. All nine isolates tested positive for the utilization of at least two out of the three hydrocarbons used which was confirmed by the increase in the number of viable cells as well as turbidity and reduction of hydrocarbon through visual inspection (Table 2 and Figure 1). The ability of these organisms to utilize these water-immiscible substrates was due to their ability to emulsify these substrates thereby 
reducing surface tension and interfacial tensions between individual molecules at the surface and interface, respectively. This is supported by the work of Calvo et al. (2004) where it was reported that biosurfactants produced by microbes during growth on water-immiscible substrates, permit their growth on such substrates by reducing the surface tension thereby making the hydrophobic substrate more readily available for uptake and metabolism. Kim, Lee, and Hwang (2000) also found that very often, the growth of microorganisms on hydrocarbons is accompanied by the emulsification of insoluble carbon sources in the culture medium and in most cases has been attributed to the production of emulsifying agents in the presence of these substrates. Several authors have reported diesel oil and crude oil as excellent substrates for microbial growth and also for biosurfactant production (Ilori et al., 2005; Adebusoye, Ilori, Amund, Teniola, \& Olatope, 2007). Tuleva et al. (2009) reported the production of rhamnolipids by $P$. putida $21 \mathrm{BN}$ when grown on $n$-hexadecane, while Kumar et al. (2006) showed that $P$. putidaIR1 also produced biosurfactants upon its growth on 2-, 3- and 4ring PAHs, but not hexadecane and octadecane, as a sole carbon and energy source.

Partial biochemical characterization of the biosurfactants produced by these isolates indicated they were heteropolymers. The analysis of the purified biosurfactants by TLC showed respective single and double spots of lipopeptides (Table 3) while the Molisch's test showed the presence of carbohydrate. These surfactants can therefore be classified as peptidoglycolipids. Peptidoglycolipids have been isolated from environmental samples by several researchers. Adebusoye et al. (2008) reported peptidogycolipid biosurfactant production from Corynebacterium spp. DDV1, Micrococcus roseus DDV3, Pseudomonas aeruginosa DDV4 and Saccharomyces cerevisae DDV5 isolated from water samples collected from University of Lagos lagoon front. Ilori and Amund (2001) reported peptidoglycolipid production by Pseudomonas aeruginosa isolated from polluted soil; Sarubbo et al. (2006) also reported peptidoglycolipid production by Candida glabrata UCP 1002 obtained from petroleum hydrocarbons contaminated soil samples. However, this is the first report of this type of biosurfactant from food waste materials. This may present an additional source of biosurfactant for the petroleum industry. The presence of various organic acids (butoxyacetic acid, hexadecanoic acid and octadecanoic acid) in the purified biosurfactants which was detected by gas chromatography is a pointer to antimicrobial properties of these biosurfactants which can be employed in the medical and pharmaceutical industries.

Biosurfactant-producing isolates were evaluated for their ability to emulsify vegetable oil and kerosene. The emulsification index can vary with bacterial growth phase, bacterial interactions and hydrophobic compound tested (Krepsky, Da Silva, Fontana, \& Crapez, 2007). The emulsification index values obtained in this work were low (16.91-28.12\%) compared with those from environmental samples (50-80\%); this might be due to substrate specificity and rates of occurrence on different hydrophobic substrates. The observed variation in activity of bacterial strains isolated from different sources could suggest that such activity is not really required for growth on spoilt foods. The ability of biosurfactants to form stable emulsions with vegetable oils and fats suggests potential application as cleaning and emulsifying agents in the food industry (Nitschke \& Pastore, 2006). The ability of these isolated biosurfactants to form stable emulsions with different hydrocarbon and vegetable oils suggests considerable potential applications in the petroleum, food and pharmaceutical industries.

\section{Conclusions}

Microorganisms from food wastes such as spoilt milk, egg, fish, tomatoes, pumpkin leaf (Telfairia occidentalis), water leaf (Talinium triangulare), rice, and vegetable salad have the ability to produce biosurfactants with emulsification activity on kerosene and vegetable oil. The hydrocarbon catabolic property coupled with biosurfactantproducing capabilities and emulsification activity of these organisms is an asset that could be exploited for clean-up of oil-contaminated environment, enhanced oil recovery and also in food industry as food formulation ingredients and anti-adhesive agents. Further work should 
be done to elucidate the functional components of these bioactive molecules and mode of action, to fully characterize their properties quantitatively and to study the best environmental conditions for these strains in order to optimize biosurfactant production and make it economically acceptable. Super-active microbial strains should be developed using genetic engineering (recombinant DNA techniques) for the manipulation of biosurfactant production at industrial level using renewable substrates as raw material.

\section{References}

Adebusoye, S. A., Amund, O. O., Ilori, M. O., Domeih, D. O., \& Okpuzor, J. (2008). Growth and biosurfactant synthesis by nigerian hydrocarbon-degrading estuarine bacteria. Revista De Biologia Tropical, $56(4), 1603-1611$.

Adebusoye, S. A., Ilori, M. O., Amund, O. O., Teniola, O. D., \& Olatope, S. O. (2007). Microbial degradation of petroleum hydrocarbons in a polluted tropical stream. World Journal of Microbiology \& Biotechnology, 23(8), 1149-1159. doi:10 . 1007/ s11274-007-9345-3

Barathi, S. \& Vasudevan, N. (2001). Utilization of petroleum hydrocarbons by Pseudomonas fluorescens isolated from a petroleum-contaminated soil. Environment International, 26 (5-6, SI), 413-416. doi:10. 1016/S0160-4120(01)00021-6

Calvo, C., Toledo, F. L., \& Gonzalez-Lopez, J. (2004). Surfactant activity of a naphthalene degrading Bacillus pumilus strain isolated from oil sludge. Journal of Biotechnology, 109(3), 255-262. doi:10.1016/j . jbiotec.2004.01.009

Cooper, D. G. \& Goldenberg, B. G. (1987). Surface-active agents from two bacillus species. Applied and environmental microbiology, 53(2), 224-229. Retrieved from http:// www.ncbi.nlm.nih.gov/ pubmed/ 16347271?dopt

Franzetti, A., Caredda, P., Ruggeri, C., La Colla, P., Tamburini, E., Papacchini, M., \& Bestetti, G. (2009). Potential applications of surface active compounds by Gordonia $s p$ strain bs29 in soil remediation technologies. Chemosphere, 75(6), 801-807. doi:10. 1016/j.chemosphere.2008.12.052

Gautam, K. K. \& Tyagi, V. K. (2006). A review of microbial surfactant. Journal of Oleo Science, 55(4), 155-166.

Holt, J. G., Krieg, N. R., Sneath, P. H., Stalely, J. T., \& Williams, S. T. (1994). Bergey's manual of determinative bacteriology. Bergey's Manual of Determinative Bacteriology. Williams \& Wilkins. Retrieved from https:// books.google.pt / books?id=jtMLzaa5ONcC

Ilori, M. O., Amobi, C. J., \& Odocha, A. C. (2005). Factors affecting biosurfactant production by oil degrading Aeromonas spp. isolated from a tropical environment. Chemosphere, 61(7), 985-992. doi:10.1016/ j.chemosphere.2005.03.066

Ilori, M. O. \& Amund, D.-I. (2001). Production of a peptidoglycolipid bioemulsifier by pseudomonas aeruginosa grown on hydrocarbon. Zeitschrift für Naturforschung $C$, $56(7-8), 547-552$.

Jain, D. K., Lee, H., \& Trevors, J. T. (1992). Effect of addition of Pseudomonas aeruginosa ug2 inocula or biosurfactants on biodegradation of selected hydrocarbons in soil. Journal of Industrial Microbiology, 10(2), 87-93. doi:10.1007/BF01583840

Kim, B. S., Lee, J. Y., \& Hwang, B. K. (2000). In vivo control and in vitro antifungal activity of rhamnolipid b, a glycolipid antibiotic, against Phytophthora capsici and Colletotrichum orbiculare. Pest Management Science, 56(12), 1029-1035. doi:10. 1002/1526-4998(200012) 56:12/1029::AIDPS238>3.0.CO;2-Q

Kitamoto, D., Isoda, H., \& Nakahara, T. (2002). Functions and potential applications of glycolipid biosurfactants - from energy-saving materials to gene delivery carriers. Journal of Bioscience and Bioengineering, 94(3), 187-201. doi:10.1263/jbb.94.187

Krepsky, N., Da Silva, F. S., Fontana, L. F., \& Crapez, M. A. C. (2007). Alternative methodology for isolation of biosurfactantproducing bacteria. Brazilian Journal of Biology, 67(1), 117-124. 
Emulsifying effect of biosurfactants produced by food spoilage organisms $\mid 21$

Kumar, M., Leon, V., Materano, A. D., Ilzins, O. A., Galindo-Castro, I., \& Fuenmayor, S. L. (2006). Polycyclic aromatic hydrocarbon degradation by biosurfactantproducing Pseudomonas sp ir1. Zeitschrift Fur Naturforschung C-a Journal of Biosciences, 61(3-4), 203-212.

Morikawa, M., Hirata, Y., \& Imanaka, T. (2000). A study on the structure-function relationship of lipopeptide biosurfactants. Biochimica et Biophysica Acta (BBA)Molecular and Cell Biology of Lipids, 1488(3), 211-218.

Mulligan, C. N. (2005). Environmental applications for biosurfactants. Environmental Pollution, 133(2), 183-198. doi:10.1016/ j.envpol.2004.06.009

Mulligan, C. N., Cooper, D. G., \& Neufeld, R. J. (1984). Selection of microbes producing biosurfactants in media without hydrocarbons. Journal of Fermentation Technology, 62(4), 311-314.

Nitschke, M. \& Pastore, G. M. (2006). Production and properties of a surfactant obtained from Bacillus subtilis grown on cassava wastewater. Bioresource Technology, 97(2), 336-341. doi:10 . $1016 / \mathrm{j}$. biortech . 2005.02.044

Olutola, P. O., Famurewa, O., \& Sonntag, H. G. (2000). An introduction to general microbiology (a practical approach). Bolabay Publications Ltd Nigeria PP, 169-180.

Patil, J. R. \& Chopade, B. A. (2001). Studies on bioemulsifier production by Acinetobacter strains isolated from healthy human skin. Journal of Applied Microbiology, $91(2), 290-298$. International Conference on Microbial Biotechnology trade and Public, OSMANIA UNIV, HYDERABAD, INDIA, SEP 15-17, 2000. doi:10.1046/j.13652672.2001.01382.x

Pinzon, N. M. \& Ju, L.-K. (2009). Improved detection of rhamnolipid production using agar plates containing methylene blue and cetyl trimethylammonium bromide. Biotechnology Letters, 31(10), 1583-1588. doi:10.1007/s10529-009-0049-7

Ron, E. Z. \& Rosenberg, E. (2001). Natural roles of biosurfactants. Environmental Microbi- ology, 3(4), 229-236. doi:10.1046/j.14622920.2001.00190.x

Sarubbo, L. A., de Luna, J. M., \& de CamposTakaki, G. M. (2006). Production and stability studies of the bioemulsifier obtained from a new strain of Candida glabrata ucp 1002. Electronic Journal of Biotechnology, 9(4), 400-406. doi:10 . 2225 / vol9 - issue4fulltext-6

Sim, L., Ward, P. O., \& Li, Z.-Y. (1997). Production and characterisation of a biosurfactant isolated from pseudomonas aeruginosa uw-1. Journal of Industrial Microbiology and Biotechnology, 19(4), 232-238. doi:10.1038/sj.jim.2900450

Tuleva, B., Christova, N., Cohen, R., Antonova, D., Todorov, T., \& Stoineva, I. (2009). Isolation and characterization of trehalose tetraester biosurfactants from a soil strain Micrococcus luteus bn56. Process Biochemistry, 44(2), 135-141. doi:10 . 1016 / j . procbio.2008.09.016

Yakimov, M. M., Timmis, K. N., Wray, V., \& Fredrickson, H. L. (1995). Characterization of a new lipopeptide surfactant produced by thermotolerant and halotolerant subsurface bacillus licheniformis bas50. Applied and Environmental Microbiology, 61(5), 1706-1713. 